DOI https://doi.org/10.30525/978-9934-26-113-8-38

\title{
ВИКОРИСТАННЯ СИТУАЦЙНИХ ЗАДАЧ \\ У ФОРМУВАННІ БІОЛОГІЧНОЇ КОМПЕТЕНЦІЇ \\ В СТУДЕНТІВ ЗАКЛАДУ ВИЩОЇ МЕДИЧНОЇ ОСВІТИ
}

\author{
Панчук О. В. \\ кандидат біологічних наук, \\ доиент кафедри біології \\ Національний медичний університет імені О. О. Богомольия
}

Старостенко О. В.

кандидат біологічних наук,

дочент кафедри біології

Національний медичний університет імені О. О. Богомольияя

Романенко О. В.

доктор біологічних наук, професор, завідувач кафедри біології

Наиіональний медичний університет імені О. О. Богомольияя

\author{
Алексієнко В. P. \\ кандидат біологічних наук, \\ асистент кафедри біології \\ Національний медичний університет імені О. О. Богомольия \\ м. Київ, Україна
}

Для закладів вищої медичної освіти актуальним є питання організації ефективної підготовки фахівців, зокрема з фізичної терапії та ерготерапії, професійна діяльність яких спрямована на забезпечення відновлення організму людини після перенесеного захворювання, на профілактику захворювань, що потребує від сьогоднішніх студентів всебічного вивчення особливостей будови та біологічних основ життєдіяльності організму людини.

Медична біологія є природничо-науковою дисципліною, важливою для формування в студентів, які опановують професію фізичного терапевта та ерготерапевта, біологічних компетентностей. Їх наявність передбачає в особистості, зокрема, здатність використовувати в майбутній практичній діяльності серед іншого: 1) знання про 
молекулярні та цитологічні основи спадковості, про механізми розвитку спадкових i набутих хвороб людини; 2) набуті вміння визначати генотипи та фенотипи нащадків за генотипами батьків, розрахувати ймовірність народження дитини 3 моногенною хворобою за відомих генотипів батьків, з'ясовувати каріотипи людей з найбільш поширеними хромосомними хворобами, будувати родовід за відповідною ознакою і проводити його аналіз, пояснювати можливі причини різних типів мутацій та зв'язок з ними спадкових хвороб людини, визначати основні методи генетики людини, характеризувати значення мутагенних та тератогенних чинників у формуванні природжених вад розвитку людини, оцінювати вплив чинників навколишнього середовища на здоров'я людини, узагальнювати заходи щодо збереження та охорони навколишнього природного середовища $[2,3]$.

Під час навчання у закладі вищої медичної освіти на формування біологічної компетентності та ключових компетентностей в майбутніх фізіотерапевтів та ерготерапевтів впливає чимало факторів. При цьому, важливим елементом коректно організованого навчального процесу $\epsilon$ його професійно-орієнтований характер, для забезпечення чого вкрай необхідним є застосування ефективних засобів навчання [1].

На формування біологічної компетентності в студентів позитивно впливає використання в навчальному процесі 3 медичної біології ситуаційних задач, які створюють зміст та структуру майбутньої професійної діяльності сьогоднішнього студента. Вони сприяють активізації в студента пізнавального інтересу, зацікавленості та мотивації до вивчення програмного матеріалу 3 навчальної дисципліни i його практичного застосування [2, 3].

При вивченні медичної біології, зазвичай, на практичному занятті та при виконанні самостійної позааудиторної роботи студентам пропонується вирішення ситуаційних задач. Це сприяє розвитку критичного мислення у майбутнього фахівця, активізує особистісно-орієнтований ефект навчання. Зміст ситуаційної задачі має узагальнювати набуті студентом теоретичні знання, що сприяє їх поглибленому аналізу та засвоєнню. Досвід використання ситуаційних задач при проведенні практичних занять з медичної біології, свідчить про їх успішне розв'язування тими студентами, в яких є фундаментальні знання з відповідного розділу навчальної дисципліни.

Формуванню практичних навичок та вмінь в студента сприяє детальний аналіз ним можливих шляхів розв'язання конкретних ситуаційних задач [3]. Контроль за можливістю застосовувати набуті знання у змодельованих ситуаціях $є$ важливим чинником, необхідним 
для розвитку в студента професійного мислення, потрібного у тому числі фахівцеві в галузі фізичної терапії та ерготерапії.

Формулюючи ситуаційну задачу, викладач має виходити з того, що в ній повинен бути наведений опис реалістичної події. Розв'язання такої ситуаційної задачі вимагає від студента активного використання раніше набутих теоретичних знань. Це в кінцевому результаті сприяє формуванню в нього цілісної картини про природничо-наукову дисципліну, що вивчається, й закріпленню вже сформованих теоретичних знань $\mathrm{i}$ асоціативних зв'язків.

Розв'язання ситуаційних задач активізує в студентів зацікавленість до неформального вивчення навчального матеріалу, є чинником формування в них біологічних основ професійної компетентності. Ефективним вбачається використання в організації навчального процесу з медичної біології й проблемно-орієнтовних ситуаційних задач.

Професія фізіотерапевта та ерготерапевта багатогранна й різноманітна у своїх проявах, передбачає індивідуальний підхід до кожного пацієнта. Тому підготовка майбутніх фахівців в галузі фізичної терапії та ерготерапії має бути практично-орієнтованою починаючи вже з першого року навчання у закладі вищої медичної освіти. Саме на це націлене, зокрема, використання ситуаційних задач в організації навчального процесу з медичної біології.

\section{Література:}

1. Вітвицька С.С. Основи педагогіки вищої школи: Методичний посібник для студентів магістратури. Київ: Центр навчальної літератури, 2003. $316 \mathrm{c}$.

2. Panchuk O.V., Kravchuk M.G., Romanenko O.V. Ways of biological competence formation in a medical student: principle of continuity. Nowoczesna edurasja: filozofia, innowacja, doswiadczenie - Nr 5. - Lodz: Wydawnictwo Naukowe Wyzszy Szkoly Informatyki I Umiejetnosci, 2016. P. 110-114.

3. Starostenko O.V., Kravchuk M.G., Dymar N.M., Romanenko O.V. The role of medical biology in the formation of medical students' professional competence. Nowoczesna edukacja: filozofia, innowacja, doświadczenie. $\mathrm{Nr}$ 2(6). Łodź: Wydawnictwo Naukowe Wyższej Szkoły Informatyki i Umiejętności, 2016. S. 125-130. 